\title{
The possibility to prevent postoperative sensitivity in resin-based composite restored teeth
}

Dragica Manojlović, Srđan Županjac, Slavoljub Živković

Stomatološki fakultet Univerziteta u Beogradu

University of Belgrade, School of Dentistry, Belgrade, Serbia
ORIGINALNI RAD (OR)

ORIGINAL ARTICLE

\section{KRATAK SADRŽAJ \\ Uvod: Postoperativna osetljivost je čest problem kod pacijenata nakon postavljanja kompozitnih ispuna na zubima. \\ Cilj ovog istraživanja je bio da se proveri klinička efikasnost oksalatnog desenzibilizatora BisBlock u pre- venciji postoperativne osetljivosti posle postavljanja kom- pozitnih ispuna na bočnim zubima. \\ Materijal i metod: Kliničko istraživanje je sprove- deno na Klinici za Bolesti zuba Stomatološkog fakulteta Univerziteta u Beogradu. U istraživanje je uključen 31 pacijent, osoba oba pola, uzrasta od 18 do 32 godine. Kod svakog pacijenta su urađena dva kaviteta druge klase na premolarima (62 kaviteta) i restaurisani kompozitnim ispunima. Jedan restaurisani zub svakog ispitanika je tre- tiran BiSBlock-m (ekperimentalana grupa) dok je drugi poslužio kao kontrolna grupa. U restaurativnoj procedu- ri kao adhezivno sredstvo je korišćen Single Bond (3M ESPE) a zubi su restaurisani kompozitnim materijalom Valux plus(3M ESPE). Procena osetljivosti je vršena posle prvog, četvrtog i sedmog dana od restauracije, ispitiva- njem osetljivosti na termičke i osmotske nadražaje i ispiti- vanjem osetljivosti na pritisak u toku mastikacije . \\ Rezultati: Dobijeni rezultati su pokazali da je upotre- bom desenzibilizatora BisBlock-a došlo do statisticki znacaj- nog smanjenja pojave postoperativne osetljivosti kod ekspe- rimentalne (3.23\%.) u odnosu na kontrolnu grupu (16.14\%).}

Ključne reči: postoperativna osetljivost, kompozitne restauracije, oksalatni desenzibilizator

Postoperativna osetljivost se često dovodi u vezu sa kompozitnim ispunima na bočnim zubima. Uprkos najnovijim dostignućima sa dentalnim restaurativnim tehnikama

\section{SUMMARY}

Introduction: Postoperative sensitivity is a common problem in patients after placement of resin-based composite $(R B C)$ restorations.

Aim: The of this study was to evaluate clinical efficacy of oxalate desensitizer BisBlock in the prevention of postoperative sensitivity after placement of $R B C$ restorations.

Materials and Methods: This clinical study was conducted at Belgrade University School of Dentistry Department of Restorative Dentistry and Endodontics. The study comprised 31 patients, both sexes, aged $18-32$. In each patient, two class II cavities were prepared in premolars (62 cavities) and restored with RBCs. One restored tooth in each patient was treated with BisBlock (experimental group) while another served as control. In the restorative procedure, Single Bond (3M ESPE) was used as the adhesive and teeth were restored with Valux Plus (3M ESPE) RBC. Sensitivity evaluation was performed at day 1, day 4 and day 7 after restoration and comprised sensitivity on thermal and osmotic stimuli as well as sensitivity during mastication.

Results: The obtained results revealed statistically significant decrease of postoperative sensitivity in experimental (3.23\%) than control group (16.14\%).

Keywords: postoperative sensitivity, resin-based composite restorations, oxalate desensitizer

Postoperative sensitivity is often related to $\mathrm{RBC}$ restorations in posterior teeth. Despite contemporary achievements in dental restorative techniques and materi- 
i materijalima, postoperativna osetljivost još uvek nije u potpunosti razjašnjena. Postoji više teorija koje objašnjavaju ovu pojavu. Nepovoljni efekti prouzrokovani preparacijom kaviteta kao što su preterano zagrevanje i dehidratacija dentina, dodatno se pogoršavaju kada se dentin, u skolopu pripreme za aplikaciju adhezivnog sredstva kondicionira kiselinom. ${ }^{1}$ Restaurativni materijali na bazi smola su takođe bili predmet brojnih istraživanja jer su smatrani toksičnim za pulpno-dentinski kompleks, pa je zato bila neophodna zaštitna barijera za dentin $u$ odbliku podloge ili lajnera. ${ }^{2,3}$ Medjutim, nedavne studije su pokazale da kiseline i restaurativni materijali nemaju štetan efekat na pulpno-dentinski kompleks ukoliko je obezbeđen adekvatan ispun i dobro zaptivanje kaviteta. ${ }^{2,4}$ Ipak, smatra se da je zaštita lajnerima i podlogama neophodna kod restauracija dubokih kaviteta kompozitnim ispunima. ${ }^{3}$

Medjutim, postoperativna osetljivost posle restauracije kompozitnim materijalima se javlja uprkos dodatnoj zaštiti pulpno-dentinskog kompleksa. Jedno od najšešćih objašnjenja ove pojave se zasniva na hidrodinamskoj teoriji. ${ }^{5}$ Delovanjem nadražaja kao što je: sušenje dentina, promena temperature, osmotski nadražaji, dolazi do kretanja tubularne tečnosti brzinom od 4-6 mm u sekundi. Hidrodinamski pritisak dovodi do pomeranja tela ćelija odontoblasta i istezanja terminalnih završetaka nervnih pleksusa, što omogućava ulazak kalijuma i depolarizaciju membrane što se oseća kao intenzivan bol. ${ }^{6}$ Kondicioniranjem dentina kiselinom dentinski kanalići ostaju široko otvoreni. Da bi se sprečilo intertubularno kretanje tečnosti a samim tim i prevencija posterapijske osetljivosti, dentinski kanalići u toku postupka restauracije kompozitnim materijalom moraju biti potpuno zatvoreni. Medjutim, tehnika aplikacije adheziva i potpuno nagrizanje dentina često predstavlja problem u ostvarivanju hibridnog sloja kao osnovnog parametra snažne adhezivne veze. ${ }^{2} \mathrm{Za}$ ovakvu vezu potreban je dentin koji nije presušen (wet bonding), adhezivno sredstvo koje će dovesti do zatvaranja dentinskih kanalića i mala polimerizaciona kontrakcija kompozitnog materijala u kavitetu. Prekid u sloju adhezivnog sistema na površini kaviteta ili mikroprozna zona ispod hibridnog sloja uzrokuje hidrodinamsko kretanje dentinske tečnosti i izaziva postoperativnu osetljivost. ${ }^{2}$ Bilo je puno pokušaja da se ovaj problem reši ali jedan od načina za redukciju postoperativne osetljivosti u kliničkoj preksi je dodatna upotreba desenzibilizatora. ${ }^{7,8,9}$ Smatra se da je efikasno sredstvo za to desenzibilizator na bazi oksalata koji se aplikuje na kiselinom nagriženi dentin neposredno pre aplikacije adheziva u cilju potpunog zatvaranja otvorenih dentinskih kanalića. Oksalatna kiselina ima afinitet za kalcijumove jone iz dentina, pri čemu dolazi do stvaranja kristala soli kalcijum oksalata. ${ }^{7,8,9}$ Aplikacijom desenzibilizatora na kondicionirani dentin, ovi kristali kalcijum oksalata zatvaraju dentinske kanaliće, i značajno redukuju hidrodinamsku provodljivost. Posle nanošenja ovog sredstva ipak ostaje slobodna površina dentina za nanošenje adheziva i impregnaciju dentina odnosno stvaranje hibridnog sloja kao ključa dobre adhezivne veze.

Cilj ovog rada je bio da se proveri klinička efikasnost oksalatnog desenzibilizatora BisBlock u prevenciji posto- als, postoperative sensitivity is not fully uncovered yet. There are several theories that explain this phenomenon. Unfavourable effects of cavity preparation such as dentine overheating and dehidration are additionaly worsened when dentine is acid-etched prior to adhesive application. ${ }^{1}$ Resin-based restorative materials have also been object of numerous studies as they were considered toxic for pulp-dentine complex and required protective barrier for dentine in the form of base or liner. ${ }^{2,3}$ However, recent studies have confirmed that acids and restorative materials do not have a deleterious effect on pulp-dentine complex if there is an adequate restoration and good cavity seal. ${ }^{2,4}$ Nevertheless, it is believed that base and liner cavity protection is necessary in deep cavities restored with RBCs. ${ }^{3}$

Postoperative sensitivity occurs after placement of $\mathrm{RBC}$ restorations in spite of the additional protection of pulp-dentine complex. One of the most common explanations of this phenomenon is based on the hydrodynamic theory. ${ }^{5}$ Stimuli like dentine desiccation, temperature and osmotic changes induce tubular fluid to move at 4-6 mm/ sec. Hydrodynamic pressure results in the movement of odontoblast cells and stretching of nerve endings which enable pottasium enter the cells and depolarize membranes which is experienced as intense pain. ${ }^{6}$ Dentine acid-etching widens dentinal tubules. In order to prevent intertubular fluid movement and, consequently, postoperative sensitivity, dentinal tubules must be completely sealed during cavity restoration with RBCs. However, total- etch technique and adhesive application often pose a problem in hybrid layer formation as the basic parameter of a strong bond. ${ }^{2}$ In order to achieve this kind of bond, non-desiccated dentine is required (wet bonding), adhesive that will seal dentinal tubules and low polymerization shrinkage of RBC in the cavity. Any discontinuity in the adhesive system or a microporous zone underneath the hybrid layer may cause hydrodynamic fluid movement and postoperative sensitivity. ${ }^{2}$ There were numerous attempts to solve this problem and one of the ways to reduce postoperative sensitivity in clinical practice is additional use of desensitizers. ${ }^{7-9}$ Oxalate-based desensitizer is believed to be efficient; it is applied on acidetched dentine immediately before adhesive application in order to completely seal dentinal tubules. Oxalate acid has the affinity towards dentinal calcium ions and crystals of calcium oxalate salts are formed. ${ }^{7-9}$ Applying the desensitizer on conditioned dentine, such calcium oxalate crystals seal dentinal tubules and significantly reduce hydrodynamic conductivity. After the application of this material, there are still enough free dentine surfaces for the application of an adhesive and hybrid layer formation. The aim of this study was to evaluate clinical efficacy of oxalate desensitizer BisBlock in the prevention of postop- 
perativne osetljivosti posle postavljanja kompozitnih ispuna na bočnim zubima.

\section{Materijal i metod}

Kliničko istraživanje je sprovedeno na Klinici za Bolesti zuba Stomatološkog fakulteta Univerziteta u Beogradu. U istraživanje je uključen 31 pacijent, (10 osoba muškog i 21 osoba ženskog pola), starosti od 18 do 32 godine. Kod svakog pacijenta su urađena dva kaviteta druge klase na premolarima (62 kaviteta) i restaurisani kompozitnim ispunima. $\mathrm{Na}$ jednom kavitetu je aplikovan desenzibilizator a drugi je korišćen kao kontrola. Svaki pacijent je informisan o načinu i tipu istraživanja u koje će biti uključen. Istraživanjem su obuhvaćeni samo zubi sa karijesom ali koji nisu pokazivali znakove oštećenja pulpodentinskog kompleksa. Da bi se isključilo postojanje ovih promena, zubi su tretirani testom toploto-hladno ( toplo gutaperka štapić i hladan nadražaj ledeni štapić ). Nadražaj je aplikovan na bukalnu površinu eksperimentalnog zuba i njegova reakcija je upoređivana sa susednim zubom. Klinička procedura kod svakog pacijenta je podrazumevala primenu lokalne anestezije. Oblikovanje kaviteta je sprovedeno dijamantskim svrdlima i visokoturažnom bušilicom uz vodeno hlađenje. Uklanjanje karijesno promenjenog dentina urađeno je okruglim karbidnim borerom. Oblik kaviteta je zavisio od veličine i obima karijesom promenjenog dentina a sve kavitete je radio jedan terapeut, trudeći se pri tome da kaviteti na oba premolara budu približno istih dimenzija. Nakon završene preparacije kaviteta, zubi su tretirani 37\% gelom fosforne kiseline koja je prvo nanošena na gleđ ( $15 \mathrm{~s}$ ) a zatim i na dentin (10 s). Kiselina je potom uklanjana vodenim mlazom u trajanju od $10 \mathrm{~s}$ a kavitet je blago posušen vazduhom iz pustera.

U eksperimentalnoj grupi površina svakog kaviteta je premazana oksalatnim desenzibilizatorom BisBlock (sl.1). Preparat je nanošen četkicom za jednokratnu upotrebu u trajanju od 30 sekundi. Površina zuba je potom isprana vodenim mlazom u trajanju od 10 sekundi. Nakon posušivanaja kaviteta aplikovan je Single Bond ( 3M ESPE ) uz pomoć četkice aplikatora. Višak rastvarača je uklonjen mlazom vazduha iz pustera u trajanju od 3 - 5 sekundi sa (udaljenosti od $5-6 \mathrm{~cm}$ ). A adheziv je prosvetljen $\mathrm{u}$ trajanju od 10 sekundi. Na tako pripremljen zub postavljana je matrica dizajnirana za rekonstrukciju aproksimalnih kaviteta ( The Palodent Sistem, Dentsply ) (sl.2) na bočnim zubima. Za fiksiranje matrica korišćen je i kočić odgovarajuće veličine kako bi se omogućio dovoljan pritisak između zuba u cilju formiranja interproksimalnog kontakta. $\mathrm{Na}$ gingivalni zid aproksimalnog kaviteta postavljen je tanak sloj tečnog kompozita Filtek Flow (3M ESPE) i prosvetljen 20 sekundi. Za restauraciju je korišćen kompozitni materijal Valux Plus (3M ESPE) koji je aplikovan u slojevima, vodeći računa da svaki sloj ne bude deblji od $2 \mathrm{~mm}$. Svaki sloj je prosvetljen 40 sekundi. Po ukljanjanju matrice, prosvetljavanje je ponovljeno jos jednom i to sa erative sensitivity after placement of $\mathrm{RBC}$ restorations in posterior teeth.

\section{Materials and methods}

The clinical study was conducted at Belgrade University School of Dentistry Department of Restorative Dentistry and Endodontics. The study comprised 31 patients, both sexes, aged $18-32$. In each patient, two class II cavities were prepared in premolars (62 cavities) and restored with RBCs. In one cavity, the desensitizer was applied while the other was used as a control. Each patient was informed about the nature of the study. The study comprised only carious teeth without the symptoms of pulp-dentine complex being affected. In order to exclude these pathologic changes, teeth were subjected to thermal hot-cold test (hot - gutta-percha stick, cold - ice stick). The stimulus was applied to buccal surface of the experimental tooth and its reaction was compared to the control tooth. Clinical procedure in each patient included local anaesthesia. Cavity preparation was performed using diamond burs in a high-speed handpiece with water-cooling. Caries was removed using a round carbide bur. Cavity shape depended on the extent of carious affected dentine and preparations were done by one therapist with an intention to prepare similar cavities in both premolars in each patient. After cavity preparation, teeth were treated with $37 \%$ phosphoric acid gel applied on enamel first (15 s) and then on dentin (10 s). Acid was removed with water jet for $10 \mathrm{~s}$ and the cavity was dried with mild air stream.

In the experimental group, the surface of each cavity was covered with the oxalate desensitizer BisBlock (fig. 1). It was applied with a disposable applicator for 30 s. Tooth surface was then subjected to water jet for $10 \mathrm{~s}$. After drying, Single Bond was applied (3M ESPE) with an applicator. The excess material was removed using air jet for 3-5 $\mathrm{s}$ at 5-6 cm distance. The adhesive was polymerized for $10 \mathrm{~s}$. Afterwards, a matrix for proximal cavity reconstruction was applied to the tooth (The Palodent System, Dentsply) (fig. 2). An adequate wedge was used for matrix fixation. A thin layer of flowable RBC was applied to the gingival wall of the proximal cavity and polymerized for $20 \mathrm{~s}$ (Filtek Flow, 3M ESPE). Valux Plus (3M ESPE) was used for cavity restoration and applied in layers no thicker than $2 \mathrm{~mm}$. Each layer was polymerized for 40 s. After matrix removal, polymerization was repeated from the buccal proximal direction. A light-curing unit of $400 \mathrm{~mW} / \mathrm{cm}^{2}$ was used for polymerization (Optilux 501 
interproksimalnog prostora sa bukalne strane. Za prosvetljavanje je korišćen aparat ( Optilux 501 Kerr ) i intezitetom svetla od $400 \mathrm{~mW} / \mathrm{cm}^{2}$. Zatim je sproveden postupak okluzalnog uravnoteženja i obrade dostupnih površina. Poliranje je urađeno $\mathrm{u}$ istoj poseti.

U kontrolnoj grupi na drugom premolaru je sproveden klasičan postupak aplikacije adhezivnog sredstva i kompozitnog materijala na identičan način kao i u eksperimentalnoj grupi ali bez desenzibilizatora.
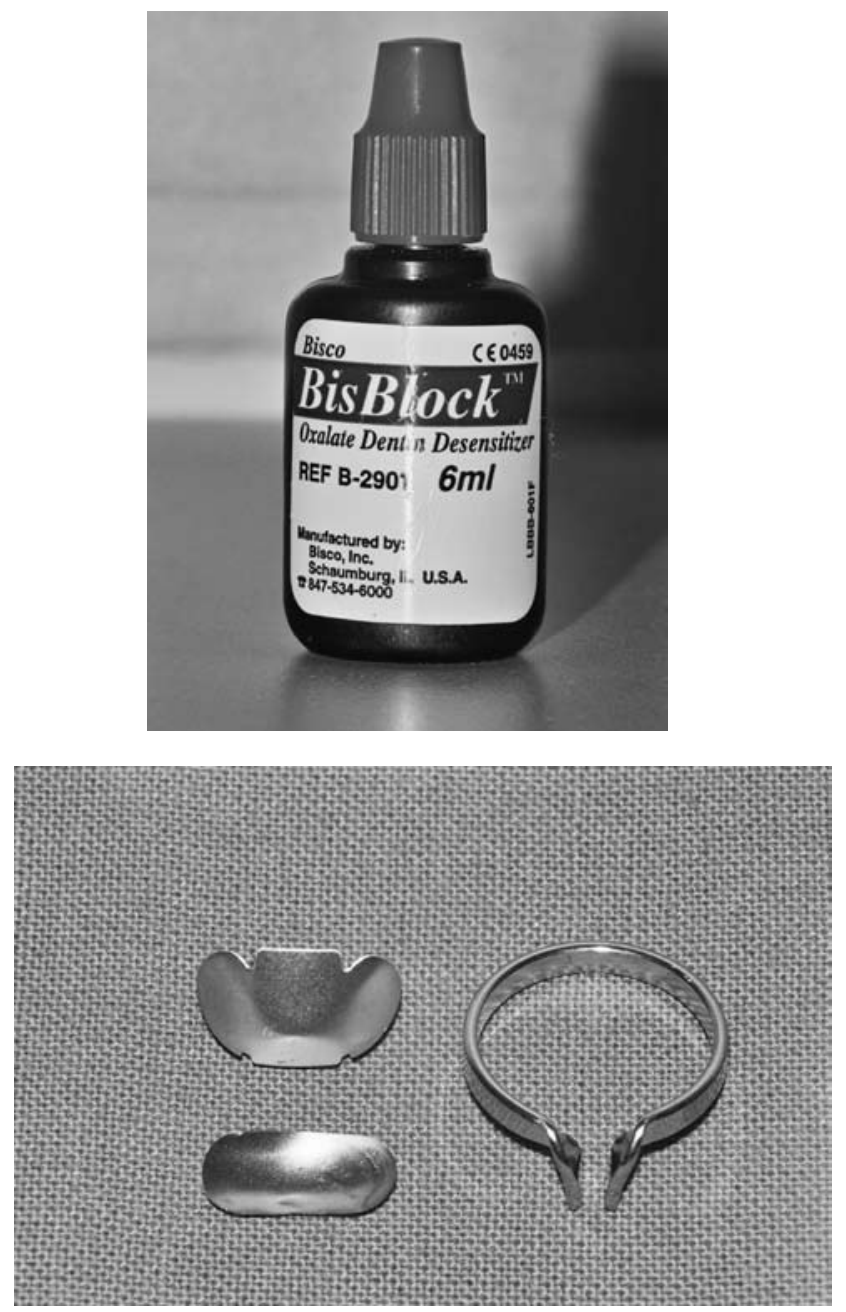

Za procenu postoperativne osetljivosti kod testiranih pacijenta korišćen je posebno pripremljen upitnik. Prvi zub kod svakog pacijenta je restaurisan prema protokolu za eksperimentalnu grupu. Po završetku restauracije pacijentu je dat upitnik da bi se registrovala eventualna pojava postoperativnog bola. Pacijent je zamoljen da ispuni upitnik kod kuće i da se javi na kontrolne preglede posle 24 časa, posle 4. i 7. dana nakon restauracije. Svaki ispitanik je osetljivost trebalo da oceni sa "Prisutna” ili „Nije prisutna” na nadražaje kao što su:

$$
\begin{aligned}
& \text { - hladna jela i pića } \\
& \text { - topla jela i pića } \\
& \text { - zaslađena hrana i pića } \\
& \text { - osetljivost na pritisak u toku mastikacije }
\end{aligned}
$$

Kerr). Subsequently, articulation was checked and restoration polished in the same visit.

In the control group, the same restorative procedure was undertaken in the contralateral premolar as in the experimental group but without applying dentine desensitizer.

Slikal. BisBlock

Figure 1. BisBlock

Slika 2. Palodent Sistem

Figure 2. Palodent System

In order to evaluate postoperative sensitivity, a specially designed questionnaire was used. The first tooth in each patient was restored according to the protocol for experimental group. After restoration, each patient was given the questionnaire for noting possible postoperative pain. Patients were asked to fill in the questionnaire and return for a follow-up after 24 hours, 4 th and $7^{\text {th }}$ day after the restoration. Each patient should mark sensitivity with "Present" or "Not present" upon the stimuli such as:

- Cold food and beverages

- Hot food and beverages

- Sweet food and beverages

- Mastication pressure 
U sledećoj poseti, pacijent je vraćao upitnik i urađena je preparacija i restauracija na drugom premolaru prema protokolu za kontrolnu grupu. I posle ovog tretmana pacijentu je dat novi upitnik. Analizu upitnika radio je isti istraživač koji je i postavio restaurativni ispun.

\section{Rezultati}

Dobijeni rezultati prikazani su u tabeli1 i na slikama 3-6
In the next visit, the patient returned the questionnaire and the second preparation and restoration were done in the opposite premolar according to the protocol for control group. After this treatment, the new questionnaire was given to the patient. One examiner, the one who placed restorations, performed questionnaire analysis.

Tabela 1. Distribucija osetljivosti zuba u odnosu na testirane nadražaje

Table 1. Distribution of tooth hypersensitivity in comparison to tested stimuli

\begin{tabular}{|c|c|c|c|c|c|c|c|c|c|c|c|c|c|}
\hline \multirow{3}{*}{ Nadražaji } & \multirow{3}{*}{ Osetljivost } & \multicolumn{6}{|c|}{ Grupa sa desenzibilizatorom } & \multicolumn{6}{|c|}{ Kontrolna grupa } \\
\hline & & \multicolumn{2}{|c|}{$24 \mathrm{~h}$} & \multicolumn{2}{|c|}{4 dan } & \multicolumn{2}{|c|}{7 dan } & \multicolumn{2}{|c|}{$24 \mathrm{~h}$} & \multicolumn{2}{|c|}{4 dan } & \multicolumn{2}{|c|}{7 dan } \\
\hline & & $\mathrm{n}$ & $\%$ & $\mathrm{n}$ & $\%$ & $\mathrm{n}$ & $\%$ & $\mathrm{n}$ & $\%$ & $\mathrm{n}$ & $\%$ & $\mathrm{n}$ & $\%$ \\
\hline \multirow{2}{*}{ Hladno } & Prisutna & 1 & 3.23 & 1 & 3.23 & 1 & 3.23 & 4 & 12.91 & 4 & 12.91 & 2 & 6.45 \\
\hline & Nije prisutna & 30 & 96.77 & 30 & 96.77 & 30 & 96.77 & 27 & 87.09 & 27 & 87.09 & 29 & 93.55 \\
\hline \multirow{2}{*}{ Toplo } & Prisutna & 0 & 0.00 & 0 & 0.00 & 0 & 0.00 & 0 & 0.00 & 0 & 0.00 & 0 & 0.00 \\
\hline & Nije prisutna & 31 & 100.0 & 31 & 100.0 & 31 & 100.0 & 31 & 100.0 & 31 & 100.0 & 31 & 100.0 \\
\hline \multirow{2}{*}{ Osmotski nadražaji } & Prisutna & 0 & 0.00 & 0 & 0.00 & 0 & 0.00 & 1 & 3.23 & 1 & 3.23 & 1 & 3.23 \\
\hline & Nije prisutna & 31 & 100.0 & 31 & 100.0 & 31 & 100.0 & 30 & 96.77 & 30 & 96.77 & 30 & 96.77 \\
\hline \multirow{2}{*}{ Pritisak } & Prisutna & 1 & 3.23 & 1 & 3.23 & 0 & 3.23 & 4 & 12.91 & 4 & 12.91 & 2 & 6.45 \\
\hline & Nije prisutna & 30 & 96.77 & 30 & 96.77 & 31 & 96.77 & 27 & 87.09 & 27 & 87.09 & 29 & 93.55 \\
\hline
\end{tabular}

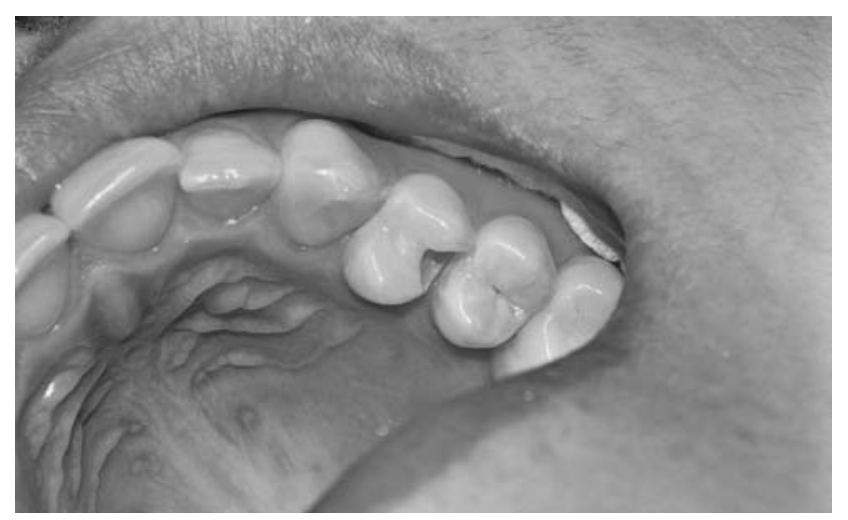

Slika 3. Kavitet druge klase na maksilarnom premolaru

Figure 3. Class II cavity in maxillary premolar

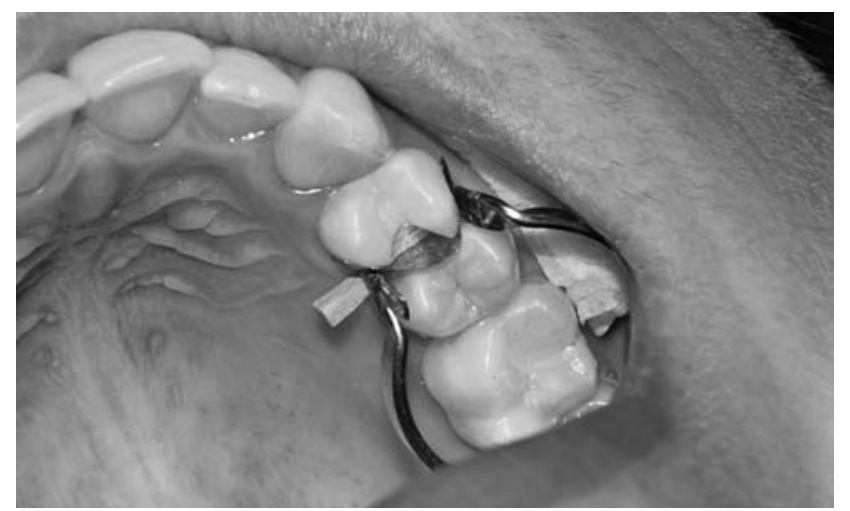

\section{Results}

The results are presented in table 1 and figures 3-6. 


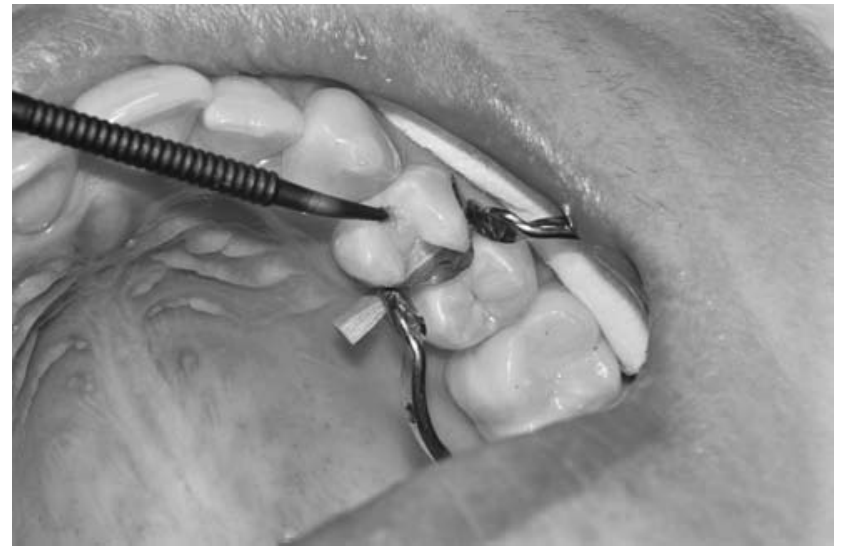

Slika 5. Nanošenje adhezivnog sredstva

Figure 5. Application of the adhesive system

Tabela 1 prikazuje broj zuba za svaku grupu, tokom perioda postoperativne procene $\mathrm{u}$ odgovoru na različite nadražaje (hladno, toplo, slatko, pritisak u toku mastikacije). Procenat potpunog odsustva postoperativne osetljivosti u eksperimentalnoj grupi, posle 1., 4., i 7 dana, a koja je procenjivana u odnosu na testirane nadražaje je iznosio: $96.77 \%$ dok je procenat potpunog odsustva postoperativne osetljivosti u kontrolnoj grupi u odnosu na iste parametre iznosio: $83.86 \%$. Posmatrano za svaki nadražaj posebno, procenat potpunog odsustva bola na nadražaj u obliku hladnih jela i pića u eksperimentalnoj grupi je iznosio $96.77 \%$ dok je u kontrolnoj taj procenat iznosio $87.09 \%$.

Na nadražaj u obliku toplih jela i pića, ni u jednoj grupi nije zabeležena osetljivost. Osetljivost na osmotske nadražaje je zabeležena samo u kontrolnoj grupi i to u jednom slučaju što odgovara procentu od $3.23 \%$

Procenat potpunog odsustva bola na pritisak u toku mastikacije u eksperimentalnoj grupi je iznosio 96.77\% dok je taj procenat u kontrolnoj iznosio $87.09 \%$.

Nije pronađena statistički značajna razlika pojave postoperativne osetljivosti u ovim grupama posmatrano $\mathrm{u}$ odnosu na vremenski opseg u kome je istraživanje sprovedeno. ( $\mathrm{P}>0.05)$ Takođe, nije postojala razlika u odgovorima na posterapijsku osetljivost posle prvog i 4.dana $\mathrm{i}$ posle 4. i 7. dana. ( $\mathrm{P}>0.05$ )

\section{Diskusija}

Aplikacija desenzibilizatora na bazi oksalata, na kiselinom kondicionirani dentin pre aplikacije adheziva je jedan od načina za izbegavanje postoperativne osetljivosti. $7,8,9$ Njegova klinička efikasnost se zasniva na sposobnosti okluzije otvorenih dentinskih kanalića stvaranjem precipitata soli kalcijum oksalata ispod površine dentina, čime se redukuje hidrodinamska provodljivist dentina. ${ }^{7,8}$ Međutim, kako je kalcijum oksalat so slabe kiseline, na njenu rastvorljivost i stabilnost direktno utiče $\mathrm{pH}$ adhezivnog sredstva. ${ }^{9}$ Prema istraživanju Yiu -a i sar, pored $\mathrm{pH}$ adhezivnog sredstva, koji utiče na stabilnost kristala kalcijum oksalata unutar

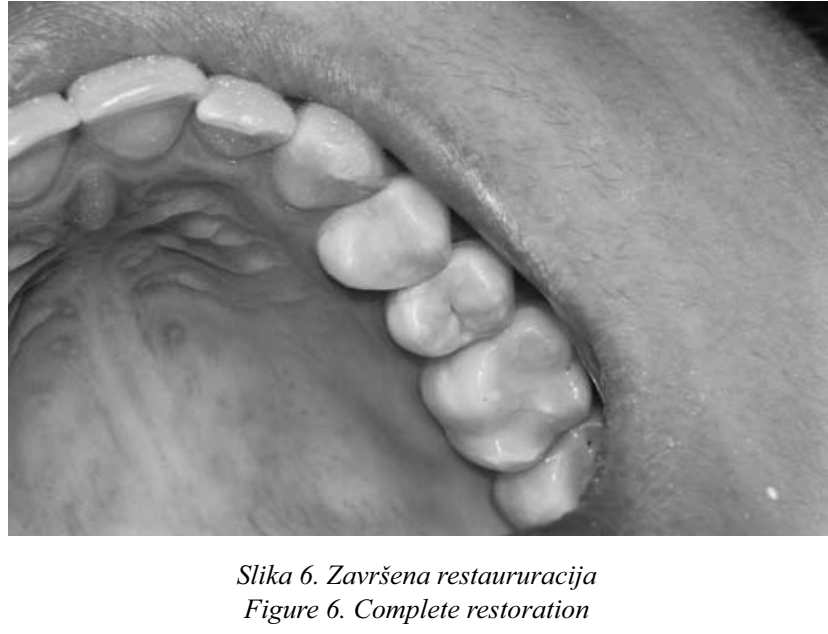

Table 1 shows the number of teeth for each group during the period of evaluation in response to various stimuli (cold, hot, sweet, mastication pressure). Complete absence of postoperative sensitivity in the experimental group after day 1 , day 4 and day 7 was registered in $96.77 \%$ of patients while this percentage in the control group was $83.86 \%$. Complete absence of postoperative sensitivity to cold food and beverages was recorded in $96.77 \%$ of patients in the experimental and $87.09 \%$ in the control group. There was no sensitivity to hot food and beverages in either group. Sensitivity to osmotic stimuli was noted in only one patient in the control group (3.23\%).

Complete absence of postoperative sensitivity to mastication pressure was seen in $96.77 \%$ of cases in the experimental and $87.09 \%$ in the control group.

There was no statistically significant difference in postoperative sensitivity in both groups in respect to the study period ( $p>0.05)$. Additionally, there was no difference after day 1 , day 4 and day $7(\mathrm{p}>0.05)$.

\section{Discussion}

The application of an oxalate-based desensitizer on acid-etched dentine before adhesive application is one of the ways to prevent postoperative sensitivity. ${ }^{7-9}$ Its clinical efficiency is based upon the possibility to occlude open dentinal tubules by forming calcium oxalate salt crystals underneath dentine surface which reduces dentine hydrodynamic conductivity. ${ }^{7,8}$ However, since calcium oxalate is a weak acid salt, adhesive $\mathrm{pH}$ directly influences its solubility and stability. ${ }^{9}$ Furthermore, based on the study by Yiu et al., fluoride content in adhesives directly influences bond strength between adhesive and dentine. ${ }^{9}$ This is explained with the fact that fluoride from the adhesive reacts with free calcium ions after dentine etching and forms spherical particles of calcium fluoride along adhe- 
tubula, sadržaj fluorida u adhezivnim sredstvima direktno utiče na jačinu veze adheziva za dentin. ${ }^{9}$ Ovo se objašnjava činjenicom da fluor iz adhezivnog sredstva reaguje sa slobodnim kalcijumovim jonima nastalim posle kondicioniranja dentina, stvarajući sferične čestice kalcijum fluorida duž kontakta adheziva i dentina. ${ }^{9}$ Njihovo prisustvo u hibridnom sloju može dovesti do stvaranja napona unutar hibridnog sloja sa posledičnim nastankom poroznih zona što se manifestuje slabljenjem veze adheziva za dentin. U ovom istraživanju korišćen je Single Bond ( $3 \mathrm{M}$ ESPE), kao slabokiseli adheziv koji sadrži minimalne količine fluorida i ne formira globularne čestice. Ovo omogućava infiltraciju adheziva $u$ kondicionirani dentin i formiranje adhezivne veze odnosno hibridizaciju demineralizovanog dentina. ${ }^{9}$

Bol, koji pacijenti osećaju posle restauracije kompozitnim ispunima se ne javlja svakodnevno. Proučavajući simptome postoperativne osetljivosti nakon kompozitnih restauracija svih tipova kaviteta, Unemori i sar. ${ }^{2}$ su pronašli da je $11 \%$ od svih zuba pokazivalo znake postoperativne osetljivosti. Ovi autori su došli do zaključka da se postoperativna osetljivost javlja i pored zaštite dentina podlogama i lajnerima. Ovu zastupljenost postoperativne osetljivosti objašnjavaju visokim procentom mladih osoba koji su bili uključeni u istraživanje. Mladi pacijenti imaju veliku komoru pulpe i široke dentinske kanaliće, zbog čega su osetljiviji na hidrodinamske nadrašaje. ${ }^{2}$

Opdam i sar. ${ }^{10}$ su našli slične rezultate, i postoperativnu osetljivost od $14 \%$ kod zuba gde su kaviteti prve klase restaurisani kompozitnim ispunima.

U svakodnevnoj praksi, nerazumevanje i pogrešna primena adhezivnih sistema i kompozitnih materijala mogu objasniti postoperativnu osetljivost uprkos napretku i razvoju adhezivnih sistema. ${ }^{1}$

U ovoj, kao i u sličnim studijama koje su sprovedene $\mathrm{u}$ cilju ispitivanja postoperativne osetljivosti, restauracije kompozitnim ispunima su urađene po unapred određenom protokolu koji je striktno praćen što može biti razlog nešto ređe pojave osetljivosti zuba nego u svakodnevnoj kliničkoj praksi. Do ovakvog zaključka došli su i Nash i sar. 11 navodeći da je postoperativna osetljivost problem koji se javlja zbog vrlo osetljive tehnike restauracije. Opdam i sar ${ }^{10}$ ističu da postoperativna osetljivost, kao jedan od glavnih faktora koji određuje klinički uspeh kompozitnih restauracija u mnogome zavisi od restaurativne tehnike primenjene od strane kliničara.

U ovom istraživanju, neznatna postoperativna osetljivost je najverovatnije posledica neadekvatne adhezivne veze odnosno propusta $\mathrm{u}$ restaurativnoj proceduri zbog kontrakcije kompozitnog materijala i formiranja mikropukotine. Time se objašnjava i odsustvo osetljivosti na osmotske nadražaje, za koje je potreban direktan kontakt osmotske supstance i dentina. ${ }^{1}$ Prisustvo osetljivosti na mehaničke nadražaje često je posledica elastične deformacije kompozitnog ispuna usled okluzalnog opterećenja koja dovodi do transmisije hidrostatskog pritiska preko tubularne tečnosti do odontoblasta. ${ }^{2}$

$\mathrm{U}$ ovom istarživanju, procena bolne osetljivosti je vršena na osnovu fiksnih kategorija ( bol je prisutan / bol sive-dentine interface. ${ }^{9}$ Their presence in the hybrid layer may result in the formation of strain within the hybrid layer with consequent porous zones that weaken adhesive bond to dentine. In this study, Single Bond was used, a weak acid adhesive with minimal quantity of fluoride and no globular particles. This enabled adhesive infiltration into etched dentine and the formation of adhesive bond i.e the hybridization of demineralized dentine. ${ }^{9}$

Pain that patients experience after placement of RBC restorations does not occur every day. Studying symptoms of postoperative sensitivity after placement of RBCs in all kinds of cavities, Unemori et al. ${ }^{2}$ reported $11 \%$ of teeth to have shown symptoms of postoperative sensitivity. These authors have concluded postoperative sensitivity occurs even despite dentine protection with liners and bases. The reported percentage of postoperative sensitivity is explained with high percent of young volunteers included in the study. Young patients have large pulp chamber and wide dentinal tubules and, therefore, more susceptible to hydrodynamic stimuli. ${ }^{2}$

Opdam et al. ${ }^{10}$ reported similar results with postoperative sensitivity in $14 \%$ of teeth with class I RBC restorations.

In everyday clinical practice, misunderstanding and inadequate application of adhesive systems and RBCs may explain postoperative sensitivity in spite of improvements and development of adhesive systems. ${ }^{1}$

In the present study, as well as others, RBC restorations were done with strict adherence to the protocol and this may be the reason for lower frequency of teeth hypersensitivity compared to routine clinical practice. The same explanation was offered by Nash et al. ${ }^{11}$ who suggested that postoperative sensitivity was due to very sensitive restoration technique. Opdam et al. ${ }^{10}$ have suggested that postoperative sensitivity, as one of critical factors for clinical success of RBC restorations, largely depends on the applied technique.

In the present study, insignificant postoperative sensitivity was most probably due to inadequate adhesivedentine bond i.e mistakes in restorative procedure originating from material contraction and microgap formation. This also explains the lack of sensitivity to osmotic stimuli as it requires direct contact between an osmotic substance and dentine. ${ }^{1}$ Sensitivity to mechanical stimuli is often the result of elastic deformation of the restoration due to occlusal loading, which leads to transmission of hydrostatic pressure through tubular fluid towards odontoblast cells. ${ }^{2}$

In the present study, sensitivity evaluation was performed based on fixed categories (pain is present / pain is not present). Another method for this evaluation is based on visual analogue scales (VAS) that are supposed to provide more efficient statistical conclusions. However, it has been 
nije prisutan ). Drugi metod za procenu osetljivosti se zasniva na primeni vizuelnih analognih skala (VAS ) koje bi trebale da obezbede efikasnije statističko zaključivanje. Međutim, primećeno je da pacijenti imaju poteškoće u reagovanju na vizuelno analogne skale, zbog čega je odlučeno da se za kategorizaciju bola koriste fiksne kategorije. ${ }^{1}$

Iako su ispitanici birani metodom slučajnog izbora, zubi uključeni u istraživanje su birani po unapred određenim pravilima kako bi se obezbedila standardizacija uzorka. Da bi se obezbedila preciznost dobijenih rezultata, restaurativni postupak i analizu dobijenih rezultata je uradio jedan istraživač. Istraživanja su potvrdila da se osetljivost javlja, obično u prvoj nedelji nakon restauracije, pa je zato i anketa sprovedena posle $24 \mathrm{~h}$ posle, 4 . i 7. dana od restauracije.

Rezultati u ovoj studiji pokazuju da je desenzibilizator na bazi oksalata efikasno sredstvo u prevenciji postoperativne osetljivosti, ali da bi se obezbedili pouzdaniji rezultati, neophodno je sprovesti klinička istraživanja na većem broju ispitanika ali i na duži vremenski period posmatranja. observed that patients have difficulties in reaction to VAS and, therefore, it was decided to use fixed pain categories. ${ }^{1}$

Even though patients were selected randomly, teeth included in the study were selected according to previously adopted criteria in order to achieve sample standardization. For precise results, a single researcher performed restorative procedure and analysis. Previous studies revealed that postoperative sensitivity occurred mostly in the first week after restoration and, therefore, the questionnaire was conducted after 24 hours, 4 and 7 days after the restoration.

Present study results suggest that oxalate-based desensitizer is an efficient mean to prevent postoperative sensitivity but larger clinical trials with longer observation periods are necessary for results that would be more conclusive.

\section{Conclusion}

$\mathrm{Na}$ osnovu dobijenih rezultata ovog istraživanja, može se zaključiti da se primenom desenzibilizatora na bazi oksalata, pojava postoperativne osetljivosti značajno smanjuje, ali da se ne može potpuno eliminisati. Striktno praćenje protokola postave kompozitnog materijala uz korišćenje desenzibilizatora, može ovu pojavu smanjiti na najmanju meru.

\section{Literatura / References}

1. Sorbal M. A. P, Garone-Neto N, Luz A. A. C, Santos A.P. Prevention of postoperative tooth sensitivity: a preliminary clinical trail. J Oral Rehabil. 2005; 32:661-668

2. Unemori M, Matsuya Y, Akashi A, Goto Y, Akamine A. Composite resin restoration and postoperative sensitivity: clinical follow-up in an undergraduate program. $J$ Dent. 2001; 29: 7-13

3. Stanley H.R, Bowen R.L, Folio J. Compatibility of various materials with oral tissue. II. J Dent Res.1979; 58: 1507-1517

4. Akimoto N, Momoi Y, Kohno A, Suzuki S, Otsuki M, Suzuki S, Cox C.F. Biocompatibility of Clearfil Liner Bond 2 and Clearfil AP-X system on nonexposed and exposed primate teeth. Quintessence Int 1998; 29:177-188.

5. Brännström M. Hydrodinamic theory, Int Dent J. 1972

6. Brännström M. Etiology of dentin hypersensitivity. Proc Finn Dent Soc. 1992; 88: 7-13

\section{Autor odgovoran za korespondenciju}

Dragica Manojlović

Klinika za bolesti zuba

Rankeova 4, 11000 Beograd

063/83-75-245

e-mail: drdragica@hotmail.com
7. Pashley DH, Carvalho RM, Pereira JC, Villanueva R, Tay $F R$ The use of oxalate to reduce dentin permeability under adhesive restorations. Am J Dent 2001; 14:89-94.

8. Tay FR, Pashley DH, Mak YF, Carvalho RM, Lai SC, Suh $B I$. Integrating oxalate desensitizers with total-etch two-step adhesive. J Dent Res 2003; 82:703-707.

9. Yiu C.K.Y, King N.M, Suh B.I, Sharp L.J, Carvalho R.M, Pashley D.H, Tay F.R. Incompatibility of Oxalate Desensitizers with Acidic, Fluoride-containing Total-etch Adhesives $J$ Dent Res 2005; 84:730-735,

10. Opdam NJM, Feilzer AJ, Roeters JJM, Smale I. class I occlusal composite resin restorations: in vivo post-operative sensitivity, wall adaptation and microleakage. Am J Dent 1998;11:229-234

11. Nash RW. Lowe RA, Leinfelder K. Using Packable composites for direct posterior placement. J Am Dent Assoc. 2001; 132:1099-1104

\section{Address for correspondence}

Dragica Manojlović

Dept. of conservative dentisrty and endodontics

Rankeova 4, 11000 Belgrade, Serbia

+381638375245

e-mail: drdragica@hotmail.com 